\title{
INTERPLAY BETWEEN PROTEAN CAREER ATTITUDE (PCA), OBJECTIVE CAREER SUCCESS (OCS) AND SUBJECTIVE CAREER SUCCESS (SCS) A STUDY OF ACADEMIA IN KSA
}

\author{
Wasmi Woishi \\ College of Business \& Administration \\ Department of MIS \\ Al Yamamah University, Riyadh, KSA
}

\author{
Razia Sultana (Supervisor) \\ College of Business \& Administration \\ Department of HR Management \\ Al Yamamah University, Riyadh, KSA
}

\begin{abstract}
This research aims to find out Protean Career Attitudes (PCA) and its individual career outcomes of Objective Career Success (OCS) and Subjective Career Success (SCS). 86 faculty members from 3 Saudi universities from Riyadh city were surveyed by the means of a closed-ended questionnaire. Data were analyzed through SPSS. This research extends PCA literature by testing Protean Career Attitude and its outcomes. Empirical evidence regarding PCA outcomes is scarce and hence undertaken in this study. The study provides a useful insight to $H R$ practitioners regarding the importance of PCA in shaping one's career outcomes (Objective Career Success \& Subjective Career Success ). In addition, this research also draws a comparison between Saudi and non-Saudi faculty members in terms of their PCA. Research findings can assist HR managers to devise training programs and career development activities which encourage and augment employees' PCA. This research adds value to the existing body of knowledge as PCA is understudied. A second distinctive aspect of this inquiry is its Saudi context which is quite ignored in PCA literature. It can provide valuable information to Saudi policymakers to prepare their human resource to meet the competitive challenges of Vision 2030.
\end{abstract}

Keywords - PCA, SCS, OCS, Protean Career Attitude, Objective Career Success, Subjective Career Success, Vision 2030, KSA

\section{INTRODUCTION}

Rapid changes are being observed throughout the world such as globalization, the technological and informational revolution, economic recession [1]. Due to the drift of economic and organizational changes, the question that crossed career researchers mind is whether career paths are changing.[2]. Traditionally career was more organization oriented as employees relied on the organization for their career path, opportunities, management and development [3]. However, to cope up with work-life pressures and increased job insecurities, employees are preferred to do contractual jobs and strive for better opportunities. These changes forced career scientists to redefine career concept [2]."A protean career attitude is one in which the person, not the organization, is in charge and where the core values are freedom and growth"[4].

Research scientists have conducted various studies to discover various outcomes of PCA. One of such outcomes is career success. Career success is very important to an individual \& to the organization itself because the employee's career success ultimately lead to organizational success. In the past, there was only one dimension considered to define career success that was objective career success. However, changes in career paths compelled career researchers to redefine career. Researchers came up with two important career aspects namely Objective Career Success (OCS) and Subjective Career Success (SCS). Both elements of career success are vital to surviving in the current turbulent career era. Therefore, research scientists are focusing to study attitudes necessary to attain both types of career success.

Empirical research on the relationships between PCA with respect to SCS \& OCS is still understudied [5]. Apart from this gap, another evident gap in protean career literature is its applicability in various cultures. Only a few studies have highlighted the influences of ethnicity and cultural background [6].

As it's a career metaphor which has originated \& tested in the western context \& might yield different results in a different 


\section{International Journal of Engineering Applied Sciences and Technology, 2019 \\ Vol. 4, Issue 4, ISSN No. 2455-2143, Pages 345-349 \\ Published Online August 2019 in IJEAST (http://www.ijeast.com)}

context, therefore, it's important to study this concept in the middle east because of the differences in their values, history, religion, political system and so on. One of the middle eastern countries is KSA. KSA's vision 2030 aims to develop to promote and reinvigorate social development to build a strong and productive society. Few types of research such as [7], [8] have been conducted. Thus, KSA offers a unique career context to study PCA.

Backed by an above-mentioned gap, this paper aims to investigate an empirical assessment of the individual PCA toward its career outcomes OCS and SCS in the context of KSA.

\section{LITERATURE REVIEW}

\section{A. Protean Career Attitude}

For over the last three decades the term protean career has been stressed over and over in the context of career development [5]. "A protean career attitude is one in which the person, not the organization, is in charge and where the core values are freedom and growth" [4]. An individual with a protean career outlook direct their own life and build expertise to develop and progress in their career [3]. There are two important components identified which are distinct but correlated with PCA, self-directed career management \& values-driven (one's own value) [9]. Individuals with a PCA have seen to maintain their career according to their own values or mindset rather than predefined organizational values and beliefs. As they pursue their career according to their values, they are said to be self-directed. "According to [9], the combination of these two attitudes results in four main career orientations (Table 1)

Table 1: Four main career orientation [9]

Dependent: Do not manage own career nor follow their own principle.

Reactive: Manages career but not follows internal values for guidance.

Rigid: Follows internal Protean career orientation: values but doesn't have a Combination of being selfself-directed attitude.
Early researchers measured a qualitative aspect of PCA in its developmental stage such as [10],[11]. First PCA scale was developed in 2006, Briscoe related PCA with self-directed career and values-driven career. Briscoe found indeed they are related but are also distinct in nature [9].

\section{B. Subjective Career Success}

The most often researched SCS is an individual's positive evaluation of his/her career. Indicators of SCS are, for example, career satisfaction and job satisfaction [12]. [9] identified SCS as a movement along the "path with a heart". Self-satisfaction purely depends on individuals. It varies from person to person or organization to organization and nation to nation.

\section{Objective Career Success}

OCS is an individual's directly observable or tangible externally measurable thing. Indicators of OCS are, for example, salary and promotions, advancement and power. OCS oriented individual feel themselves valuable for other organizations and employers, employees are confident and believe finding a new job is easier. OCS oriented people tend to change their jobs easily wherever they find a better job with better salary and promotions. The higher the salary is, the higher the chance of an individual of being OCS oriented [13]. Although OCS is prominent it needs further investigation.

\section{Linkages between PCA and SCS and OCS}

People with a PCA self-inquiry to a higher extent, implying that they contemplate why they engage in certain behaviors. Those who learn and evaluate continuously by themselves its easier for them to adopt new working environments [12],[15]. A PCA personality accomplishes their own career independently [14]. These kinds of persons show flexibility and have positive insight regarding career changes such as layoffs and changes in the labor market because of their positive attitude toward OCS [15]. Individuals considered to have the authority to manage their own career thus a protean career influenced by their individual related variables [16]. [15] studied the relationship between PCA and SCS and found that SCS is the significant predictor of PCA. [17] studied German executives and found that a PCA (i.e., self-directed career management) was positively associated with career satisfaction and SCS [12]. [9] found positive associations between both outcomes SCS \& OCS of the PCA scale and proactive personality. However, [17] found no relationships between a values-driven career attitude and SCS or OCS. Researchers such as [18] found positive relationships between these related constructs and SCS \& OCS. Several researchers such as [19], [20] have been found a positive relationship with career satisfaction and professional vitality, and with job satisfaction. This was expected as having a protean career orientation reflects an interest in achieving self-set goals and applying one's capacity to do so [4]. However, some researchers found different outcomes such as [21] found a negative relationship between protean career orientation job involvement and job utility in a sample of Singaporean employees. 


\section{International Journal of Engineering Applied Sciences and Technology, 2019 \\ Vol. 4, Issue 4, ISSN No. 2455-2143, Pages 345-349 \\ Published Online August 2019 in IJEAST (http://www.ijeast.com)}

Although most of the studies suggest positive relationships PCA with SCS \& OCS fewer empirical findings have been reported. Above-mentioned researches are showing mixed findings. Thus, the relationship between PCA and its outcomes are inconclusive.

Hypothesis 1: PCA is positively related to SCS in terms of career satisfaction

Hypothesis 2: PCA is positively related to OCS in terms of salary

In addition, the researchers have argued that it's developed and tested in western contexts thus it is needed to test it in different contexts. Now researchers call for testing PCA in nonwestern context. Especially in KSA which is passing through pragmatic shifts in its social and business environment. Appropriate plans, policies, and procedures are required to develop and prepare the workforce. One of the goals of vision 2030 to increase the participation of the Saudi workforce in the different business sector. The Saudi work environment is the mixture of Saudi and Non-Saudi workforce. One of the study objectives is to understand the PCA measure between the Saudi and non-Saudi workforce in the kingdom. Thus, it's essential to study on PCA and its outcomes SCS and OCS to fill the gap. Thus, this research paper hypothesizes:

Hypothesis 3: Non-Saudi workforce is more protean than Saudi workforce (it's a general assumption that non-Saudi are from different countries, so they are more focused, dedicated and hardworking toward their work)

Theoretical Framework

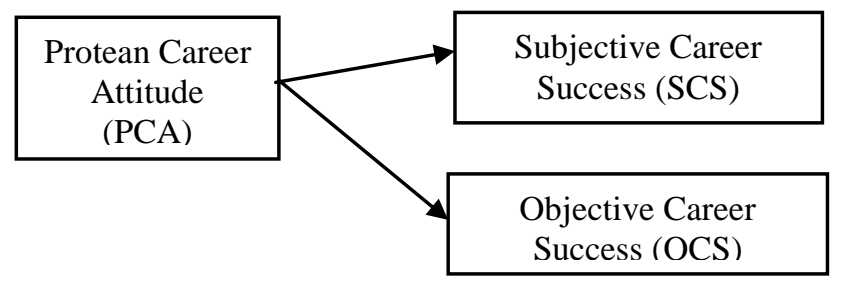

\section{METHODOLOGY}

\section{A. Questionnaire Design \& Sample Size}

86 faculty members were randomly selected from 3 private universities, Riyadh Elm University, Al Yamamah University \& Princess Nora University operating in Riyadh. Closedended questionnaires along with the cover letter were distributed through email and in person. The questionnaire consists of 20 questions and has 3 sections. Section 1: personal information, Section 2: PCA questions, Section 3: SCS questions \& Section 4: OCS questions. Some questions were reverse coded for a more authentic response.

\section{B. Research Design}

The study uses a correlation design that aims to investigate the PCA among faculty members and to examine the relationship between SCS and OCS. The study measured mean, frequency charts, correlation and reliability analysis (Cronbach's alpha) using SPSS statistical tool. Cronbach's alpha was assessed to check the reliability of the questionnaire.

\section{ANALYSIS}

Table 2 shows a survey from 86 respondents, 28 of them are male and 58 of them are female. Furthermore, the mean age of our respondents was 31-40. Moreover, the mean qualification of our respondents was masters and the mean of work experience was 11-15 years. Additionally, the mean of the PCA was significant 3.90 indicating strong exposure of protean career attitude among participants \& the mean of the SCS was 3.39 indicating the positive effect of SCS.

Table 2: Personal Information (Mean, Frequency and Standard Deviation Statistics)

\begin{tabular}{|c|c|c|c|c|}
\hline \multicolumn{2}{|c|}{ Variable } & Mean & Frequency & Standard \\
\hline 1. Gender & $\begin{array}{l}\text { 1. Male } \\
\text { 2. Female }\end{array}$ & 1.67 & $\begin{array}{l}28 \\
58\end{array}$ & 0.47 \\
\hline 2. Age & $\begin{array}{l}\text { 1. } 20-30 \\
\text { 2. } 31-40 \\
\text { 3. } 41-50 \\
\text { 4. } 51+ \\
\end{array}$ & 2.01 & $\begin{array}{l}28 \\
34 \\
19 \\
5\end{array}$ & 0.88 \\
\hline $\begin{array}{l}3 . \\
\text { Qualification }\end{array}$ & $\begin{array}{l}\text { 1. Bachelors } \\
\text { 2. Masters } \\
\text { 3. M.Phil. } \\
\text { 4. PhD } \\
\text { 5. Post.doc }\end{array}$ & 2.19 & $\begin{array}{l}18 \\
51 \\
01 \\
14 \\
2\end{array}$ & 1.02 \\
\hline $\begin{array}{l}\text { 4. Work } \\
\text { Experience }\end{array}$ & $\begin{array}{l}\text { 1. } 0-5 \text { years } \\
\text { 2. } 6-10 \text { years } \\
\text { 3. } 11-15 \text { years } \\
\text { 4. } 16-20 \text { years } \\
\text { 5. } 20+\end{array}$ & 2.38 & $\begin{array}{l}28 \\
25 \\
12 \\
14 \\
07\end{array}$ & 1.31 \\
\hline $\begin{array}{l}\text { 5. Are you } \\
\text { Saudi? }\end{array}$ & $\begin{array}{l}\text { 1. Yes } \\
\text { 2. No }\end{array}$ & 1.57 & $\begin{array}{l}37 \\
49 \\
\end{array}$ & 0.49 \\
\hline 6. $P C A$ & & 3.90 & 86 & 0.54 \\
\hline 7. $S C S$ & & 3.39 & 86 & 0.69 \\
\hline 8. Salary & $\begin{array}{l}\text { 1. No response } \\
\text { 2. } 10,000-15,000 \\
\text { 3. } 15,000-20,000 \\
\text { 4. } 20,000-25,000 \\
\text { 5. } 25,000-30,000 \\
\text { 6. } 30,000+\end{array}$ & 1.15 & $\begin{array}{l}37 \\
18 \\
19 \\
07 \\
03 \\
02\end{array}$ & 1.28 \\
\hline
\end{tabular}

The most significant correlations are PCA with SCS (Table 3). Table 4 shows PCA's Cronbach's alpha is 0.783 and SCS's Cronbach's alpha is 0.872 . Both are above 0.7 which means the study is reliable. Furthermore, the correlation between 
PCA and SCS is 0.42 which shows a positive relationship between PCA and SCS. In addition to this, the correlation between PCA and OCS is 0.01 which shows a negative relationship between PCA and OCS.

Table 3: Correlation statistics

\begin{tabular}{|c|c|c|c|c|c|c|c|c|}
\hline & 1 & 2 & 3 & 4 & 5 & 6 & 7 & 8 \\
\hline $\begin{array}{c}1 . \\
\text { Gender }\end{array}$ & 1 & & & & & & & \\
\hline 2. Age & 0.35 & 1 & & & & & & \\
\hline $\begin{array}{c}3 . \\
\text { Qualific } \\
\text { ation }\end{array}$ & 0.35 & 1.00 & 1 & & & & & \\
\hline $\begin{array}{c}\text { 4. Work } \\
\text { Experie } \\
\text { nce }\end{array}$ & 0.14 & 0.31 & 0.31 & 1 & & & & \\
\hline $\begin{array}{c}\text { 5. Are } \\
\text { you } \\
\text { Saudi? }\end{array}$ & 0.09 & 0.07 & 0.07 & 0.40 & 1 & & & \\
\hline 6. PCA & 0.05 & 0.16 & 0.16 & 0.07 & 0.03 & 1 & & \\
\hline 7. SCS & -0.10 & 0.12 & 0.12 & 0.20 & - & $\mathbf{0 . 4 2}$ & 1 & \\
\hline $\begin{array}{c}\text { 8. OCS } \\
\text { (1) }\end{array}$ & -0.15 & -0.05 & -0.05 & 0.02 & - & $\mathbf{0 . 0 1}$ & 0.21 & 1 \\
\hline
\end{tabular}

Table 4: Cronbach's alpha \& reliability statistics

\begin{tabular}{|l|l|}
\hline & Cronbach's alpha \\
\hline PCA & 0.783 \\
\hline SCS & 0.872 \\
\hline
\end{tabular}

Moreover, PCA in the Saudi workforce is 3.88 non-Saudi workforce is 3.91 (Table 5). It's proven, Saudi workforce and non-Saudi workforce are equally protean.

Table 5: Protean career attitude among Saudi and non-Saudi workforce

\begin{tabular}{|c|c|c|c|}
\hline $\begin{array}{c}\text { Are you } \\
\text { Saudi? }\end{array}$ & Mean & $\mathrm{N}$ & Standard Deviation \\
\hline Yes & 3.88 & 37 & 0.51 \\
\hline No & 3.91 & 49 & 0.57 \\
\hline Total & $\mathbf{3 . 9 0}$ & $\mathbf{8 6}$ & $\mathbf{0 . 5 4}$ \\
\hline
\end{tabular}

\section{RESULTS \& DISCUSSION}

As the correlation between PCA and SCS is 0.42 that means PCA is positively related to SCS. Thus, our first hypothesis is accepted. The correlation between PCA and OCS is 0.01 that shows PCA is negatively related to OCS in our study. Thus, our second hypothesis is rejected. Saudi's protean rate \& nonSaudi protean rate is respectively $3.88 \& 3.90$ thus the third hypothesis is rejected.

\section{THEORETICAL \& PRACTICAL IMPLICATION}

The study is adding value to the PCA literature. The study is encouraging organizations to acknowledge the role of PCA in shaping organizational success and employee performance. It's benefitting HR practitioners to develop training programs to satisfy the protean needs of the employees.

\begin{tabular}{|lcl|} 
Hypothesis 1: & $\begin{array}{c}\text { PCA is positively related } \\
\text { SCS in terms of career } \\
\text { satisfaction }\end{array}$ & Accepted \\
\hline Hypothesis 2: & $\begin{array}{c}\text { PCA is positively related } \\
\text { OCS in terms of salary }\end{array}$ & Rejected \\
\hline Hypothesis 3: & $\begin{array}{c}\text { The non-Saudi workforce } \\
\text { is more protean than } \\
\text { Saudi workforce }\end{array}$ & Rejected \\
\hline
\end{tabular}

The study is adding value in accomplishing VISION 2030 goals \& may help Saudi managers in developing skills and competency among Saudi employees.

\section{LIMITATION}

There are some limitations to this study. SCS and OCS are determinants of PCA, and both should be studied separately. In addition, further study is recommended in working environments such as among doctors, engineers. bankers etc.

\section{CONCLUSION}

This study tested PCA among faculty members in KSA. There is a significant relationship between PCA and SCS. However, there is a negative relationship between PCA and OCS. It means a person can be satisfied with their job regardless of the amount of the paid amount. Saudi's protean rate is 3.88 in our study which indicates that Saudi's have the quest for learning. The government can provide the Saudi workforce with different opportunities to comply with the competitive skills needed to develop the country.

\section{Acknowledgment}

I would like to express my deep gratitude to Ms. Razia Sultana for her valuable and constructive suggestions during the planning and development of this research work. Her willingness to give her time so generously has been highly appreciated.

\section{REFERENCE}

[1] Kovalenko, M., \& Mortelmans, D. (2010). Determinants of alternative career paths. An international comparison of the empirical literature, 103. 


\section{International Journal of Engineering Applied Sciences and Technology, 2019 \\ Vol. 4, Issue 4, ISSN No. 2455-2143, Pages 345-349 \\ Published Online August 2019 in IJEAST (http://www.ijeast.com)}

[2] Kattenbach, R., Lücke, J., Schlese, M., \& Schramm, F.(2011). Same same but different-Changing career expectations in Germany? German Journal of Human Resource Management, 25(4), 292-312.

[3] Supeli, A., \& Creed, P. A. (2016).The longitudinal relationship between protean career orientation and job satisfaction, organizational commitment, and intention-toquit. Journal of Career Development, 43(1), 66-80.

[4] Hall, D. T. (1996). Protean careers of the 21st century. The academy of management executive, 10(4), 816.

[5] Park, Y., \& Rothwell, W. J. (2009). The effects of organizational learning climate, career-enhancing strategy, and work orientation on the protean career. Human Resource Development International, 12(4), 387-405.

[6] Gubler, M., Arnold, J., \& Coombs, C. (2014). Reassessing the protean career concept: Empirical findings, conceptual components, and measurement. Journal of Organizational Behavior, 35(S1).

[7] Lin, Y. C. (2015). Are you a protean talent? The influence of protean career attitude, learning-goal orientation and perceived internal and external employability. Career Development International, 20(7), 753-772.

[8] Zafar, J., \& Mat, N. B. (2012). Protean career attitude, competency development \& career success: A mediating effect of perceived employability. International Journal of Academic Research in Business and Social Sciences, 2(4), 204

[9] Briscoe, J. P., \& Hall, D. T. (2006). The interplay of boundaryless and protean careers: Combinations and implications. Journal of vocational behavior, 69(1), 4-18.

[10]King, Z. (2003). Career self-management: its nature, causes and consequences. Journal of Vocational Behavior, 65(1), 112-133.

[11]Baruch, Y. (2004). The academic career: A model for future careers in other sectors. Journal of Vocational Behavior, 64, 241-262.

[12] Volmer, J., \& Spurk, D. (2011). Protean and boundaryless career attitudes: Relationships with subjective and objective career success. Zeitschrift für ArbeitsmarktForschung, 43(3), 207-218.

[13] Guo, W., Xiao, H., \& Yang, X. (2012). An empirical research on the correlation between human capital and career success of knowledge workers in enterprise. Physics Procedia, 25, 715-725.

[14]De Vos, A., \& Soens, N. (2008). Protean career attitude and career success: The mediating role of selfmanagement. Journal of Vocational behavior, 73, 449456.
[15]Hall, D.T. (2002). Careers in and out of organizations. Thousand Oaks, CA: Sage.

[16] Wong, S. C., \& Mohd Rasdi, R. (2015). Predictors of protean career and the moderating role of career strategies among professionals in Malaysian Electrical and Electronics (E \& E) Industry. European Journal of Training and Development, 39(5), 409-428.

[17] Gasteiger, R. M. (2007). Selbstverantwortliches Laufbahnmanagement: Das proteische Erfolgskonzept. Hogrefe Verlag.

[18] Abele, A.E., and Spurk, D. (2009). The Longitudinal Impact of Self-Efficacy and Career Goals on Objective and Subjective Career Success, Journal of Vocational Behavior, 74, 53-62.

[19] Grimland, S., Vigoda-Gadot, E., \& Baruch, Y. (2012). Career attitudes and success of managers: the impact of chance event, protean, and traditional careers, The International Journal of Human Resource Management, 23(6), 1074-1094.

[20] Cerdin, J. L., \& Le Pargneux, M. (2014). The impact of expatriates' career characteristics on career and job satisfaction, and intention to leave: an objective and subjective fit approach, The International Journal of Human Resource Management, 25(14), 2033-2049.

[21]Chay, Y. W., \& Aryee, S. (1999). Potential moderating influence of career growth opportunities on careerist orientation and work attitudes: Evidence of the protean career era in Singapore. Journal of Organizational Behavior, 613-623, Resource Management, 23(6), 10741094. 